\title{
Isolation and characterization of a very virulent Infectious bursal disease virus from turkey
}

\author{
J. RAZMYAR, S.M. PEIGHAMBARI
}

Department of Clinical Sciences, Faculty of Veterinary Medicine, University of Tehran, Tehran, P.O. Box 14155-6453, Iran

Received March 26, 2009; accepted September 9, 2009

\begin{abstract}
Summary. - Infectious bursal disease (IBD) is a highly contagious disease of chickens caused by Infectious bursal disease virus (IBDV). In turkeys, however, infection with classical virulent IBDV strains lead only to subclinical forms of the disease. We attempted to isolate IBDV from the bursa of turkey and characterize it. Amplification of a 743-bp fragment of VP2 gene by RT-PCR and restriction analysis of the product showed a pattern compatible with very virulent IBDV (vvIBDV). Comparison of the sequence of this isolate with those of other IBDVs and phylogenetic analysis confirmed very virulent nature of the isolate. This is the first report on the isolation of vvIBDV from turkey in Iran.
\end{abstract}

Keywords: Infectious bursal disease virus; very virulent isolate; turkey; Iran

\section{Introduction}

IBD is a highly contagious disease of young chickens (Eterradossi and Saif, 2008). The causative virus of this disease IBDV is a member of the family Birnaviridae. The virus genome consists of two double-stranded RNA segments that encode several proteins. VP2 is major immunogenic protein of IBDV (Müller et al., 2003). Two serotypes of IBDV have been identified by cross-neutralization assays. While the serotype 1 is the pathogenic type causing IBD in chickens, the serotype 2 produces neither disease nor immunity against the serotype 1 (Eterradossi and Saif, 2008). IBDV is distributed in the poultry populations worldwide. vvIBDV strains were initially reported from Europe in the late 1980s and later they were spread around the world except North America and Australia (Sapats and Ignjatovic, 2000; van den Berg, 2000).

To date, only chickens have shown clinical symptoms of IBDV infection. However, natural infections of turkeys with

"Corresponding author. E-mail: mpeigham@ut.ac.ir; fax: +982166933222.

Abbreviations: IBD = infectious bursal disease; IBDV = IBD virus; vvIBDV = very virulent IBDV both IBDV serotypes without any clinical symptoms have been described (McNulty et al., 1979; Chin et al., 1984; McNulty and Saif, 1988; Owoade et al., 2004). Turkey poults infected experimentally with IBDV serotype 1 developed only subclinical form of IBD with microscopic pathological signs in the bursa of Fabricius (Giambrone et al., 1978). The first isolation and identification of vVIBDV in turkeys was reported by Owoade et al. (2004) in Nigeria. The presence of vVIBDVs in chickens has been previously shown in Iran (Hosseini et al., 2004; Shamsara et al., 2006; Razmyar and Peighambari, 2008a). However, no report has indicted the isolation and molecular characterization of IBDV from turkeys in the country.

In this study, we attempted to isolate IBDV from the bursa of turkey and characterize it by RT-PCR and restriction, sequencing and sequence and phylogenetic analyses. The isolate turned out to be a vV IBDV first time isolated from turkey in Iran.

\section{Materials and Methods}

Samples. Three frozen bursal samples from a 10-week-old small flock of turkeys suffering $7 \%$ mortality were submitted to our laboratory. The samples were placed in tubes containing TNE 
buffer (10 mmol/l Tris/HCl, $100 \mathrm{mmol} / \mathrm{l} \mathrm{NaCl}, 1 \mathrm{mmol} / \mathrm{l}$ EDTA, $\mathrm{pH}$ 8.0 ) and the volume was increased 5 times by TNE buffer. Penicillin and streptomycin, $10,000 \mathrm{IU}$ and $10,000 \mathrm{mg} / \mathrm{ml}$, respectively, were added to the suspension. The bursal homogenates were stored at $-70^{\circ} \mathrm{C}$ until used (Rosenberger et al., 1998).

$R T-P C R$. A commercial kit (RNX plus kit; Cinnagen) was used to extract the total RNA from the bursal samples homogenized in TNE buffer as recommended by the manufacturer. To make cDNA, a commercial cDNA synthesis kit (Fermentas Life Science) was used. The procedure recommended by manufacturer was utilized with some modifications (Razmyar and Peighambari, 2008a). The RT-PCR developed by Sapats and Ignjatovic (2002) was used to amplify a 743-bp sequence (nt 736-1481) of IBDV VP2 gene using primers J1 (5'-GGC CCA GAG TCT ACA CCA TAA C-3') and J2 (5'-CCG GAT TAT GTC TTT GAA GCC-3'). The primers and other materials used in the PCR reaction were provided by Cinnagen. The PCR amplification and gel electrophoresis of the PCR products was carried out as previously described (Razmyar and Peighambari, 2008a).

Restriction analysis. The PCR amplification product was purified using purification kit (Roche) and digested with two restriction enzymes BspMI and SacI according to the manufacturer's instructions (Fermentas Life Science) (Razmyar and Peighambari, 2008b). All reactions were done in duplicates.

Sequencing and phylogenetic analysis. The 743-bp PCR product was purified using the Roche purification kit and submitted for an automated sequencing in both directions at the Eurofins MWG Operon (Martinsried) using PCR primers as the sequencing primers. Nucleotide and predicted amino acid sequence data were aligned with Clustal alignment algorithm. Phylogenetic analysis based on the nucleotide sequences was conducted using a distance method, unweighted pair group with arithmetic mean, and by calculating bootstrap values for 1000 replicates in CLC Sequence Viewer 6 (CLC Bio).

\section{Results and Discussion}

This investigation was initiated when we received bursal samples from a 10-week-old turkey flock of 1000 birds at our veterinary hospital. The flock was suffering about $7 \%$ mortality without any obvious gross pathological findings except enlargement and congestion of the bursa of Fabricius. In the end, the flock encountered respiratory complications and a microbe Escherichia coli was isolated from the lungs and blood of dead birds. The pooled bursae were positive in RT-PCR for IBDV sequences and yielded identical bands with other IBDV strains available in our laboratory (Razmyar and Peighambari, 2008b). Previously, Zierenberg et al. (2001) differentiated classical and vvIBDV strains using SacI and BspMI. This finding was further confirmed in our experiments with 37 IBDV field isolates (Razmyar and Peighambari, 2008b). Using BspMI and SacI, the Iranian turkey IBDV isolate (JRMPT45IR) produced the same pattern as reference strain, UK661 (Fig. 1). The BspMI cleavage site found in vVIBDV strains was correlated with the amino acid (aa) position 222 (proline to alanine) in the major hydrophilic peak A of the VP2 hypervariable region. This aa exchange was conserved in all published typical vvIBDVs (Zierenberg et al., 2000; Kataria et al., 2001; Razmyar and Peighambari, 2008a). Some IBDV isolates as the West African strain 88180 may lack the cleavage sites for restriction enzymes due to silent mutations (Zierenberg et al., 2001).

In our previous work, we analyzed 9 Iranian IBDV isolates from chickens and 6 of them belonged to vvIBDVs based on the nucleotide and amino acids sequence data (Razmyar and Peighambari, 2008a). Phylogenetic analysis based on nucleotide sequences separated Iranian vvIBDV isolates into two clusters. One cluster, including 5 isolates such as JRMP13IR, was closely related to BD3/99 strain from Bangladesh. The other one that included isolate JRMP42IR was closely related to the European and Asian isolates UK661, GZ96, HK46, UPM94, and also to two Iranian isolates, IR01 and SDH1.

In this study, the result of sequence analysis of the isolate JRMPT45IR was compared with published sequences of other isolates using Clustal method at the nucleotide level (nt 760-1191) and predicted amino acids (aa 211-354). The IBDVs used for comparison included one representative isolate from each of two Iranian isolate clusters (JRMP13IR and JRMP42IR), a turkey strain (NIE009t) from Nigeria (Owoade et al., 2004), and some European and Asian isolates. Acc. No. of the turkey IBDV isolate (JRMPT45IR) and sequences used for multiple alignment analysis are shown in Fig. 2.

Based on the nucleotide and amino acid sequence data, two Iranian isolates, JRMP13IR and JRMPT45IR from chicken and turkey origin, respectively, were $100 \%$ identical. Nucleotide differences at 18 positions were common between Iranian turkey isolate and most of Iranian, European, and Asian strains of vvIBDVs, when compared with those of the F52/70 strain (Table 1). Five uncommon or less reported nucleotide differences 802A, 847T, 934A, 940A, and 997C were also observed in Iranian turkey isolate. Difference at the position 802 was reported in three Chinese isolates and at the position 934 only in one Chinese isolate (Cao et al., 1998). The nucleotide differences $802 \mathrm{~A}, 934 \mathrm{~A}, 940 \mathrm{~A}$ were also noted among Bangladeshi isolates (Islam et al., 2001). In the genome region from nt 761-1191, there were $16 \mathrm{nt}$ differences between the two Iranian and Nigerian turkey isolates (Table 1).

Amino acid sequence analysis of the Iranian turkey isolate demonstrated the same 4 aa differences (222A, 256I, 294I, 299S) conserved in all published typical vvIBDV isolates (Table 2). These differences, however, may not be unique to vvIBDV. Some of these differences have been found also in classical or variant strains of IBDV (Kibenge et al., 1991; Sapats and Ignjatovic, 2000). The West African vvIBDV strain 88180 showed differences at 222Q, 294L, and 299N (Eter- 
(a)

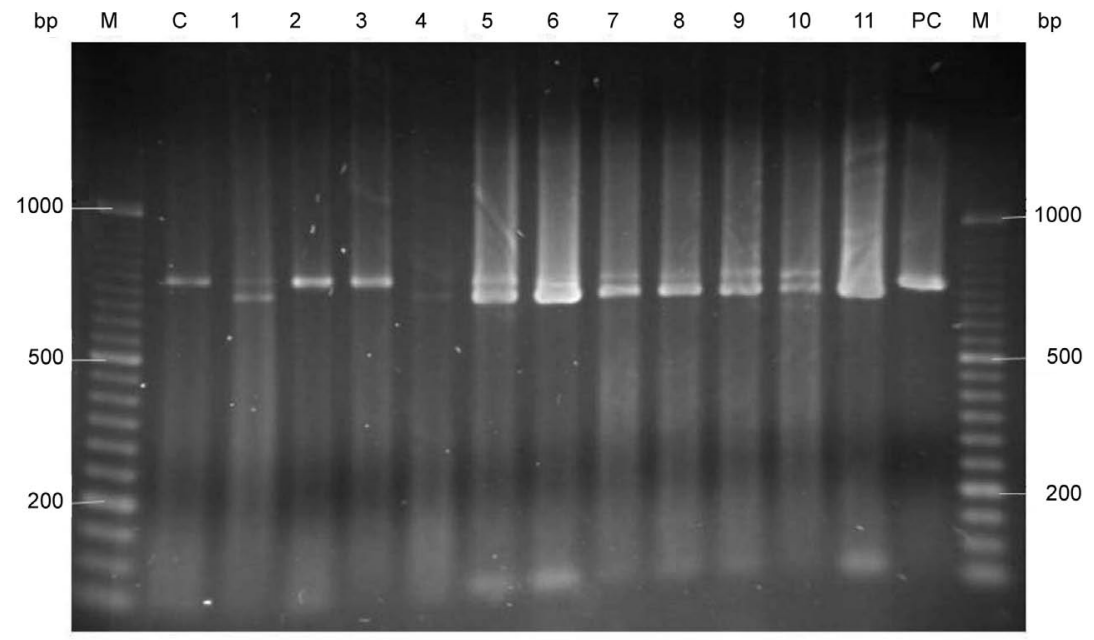

(b)

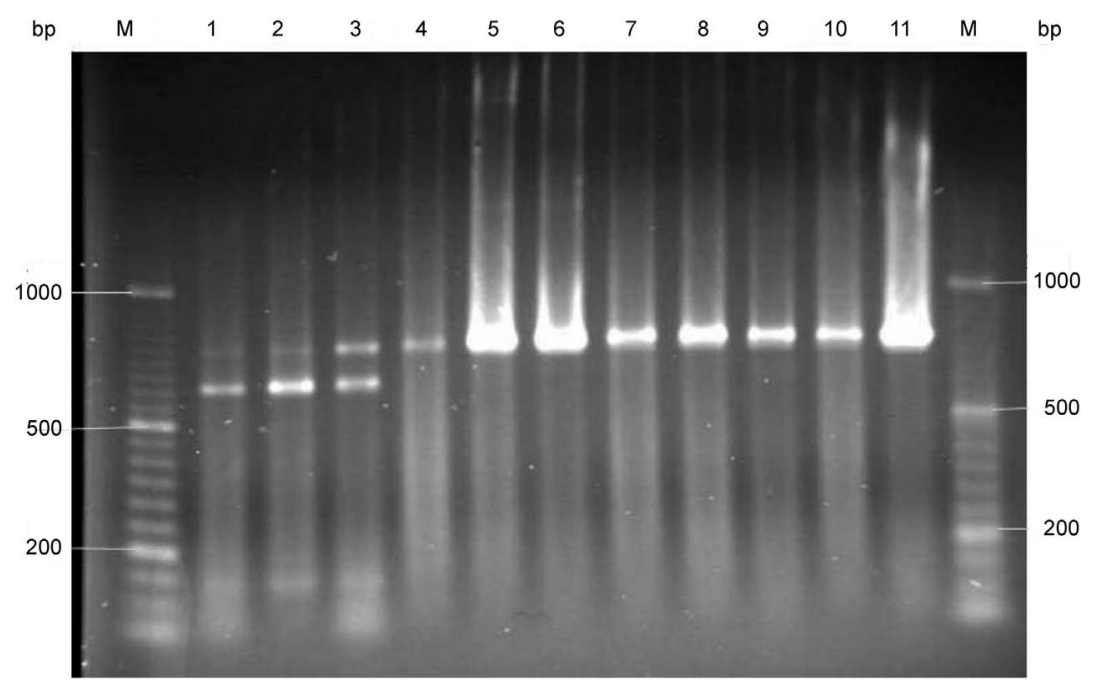

Fig. 1

Agarose gel electrophoresis of restriction analysis products of Iranian turkey IBDV isolate and selected IBDV strains with BspMI (a) and $S a c$ I (b) (a) D78 vaccinal strain (lane C), classical IBDV field isolates (lanes 2, 3), vvIBDV field isolates (lanes 1, 4, 8-11), isolates JRMP13IR, JRMP42IR, JRMPT45IR (lanes 5, 6, 7, respectively), positive control - untreated vvIBDV isolate (lane PC); (b) classical IBDV field isolates (lanes 1-3), vvIBDV field isolates (lanes 4, 8-11), isolates JRMP13IR, JRMP42IR, JRMPT45IR (lanes 5, 6, 7, respectively). 50 bp ladder (lanes M).

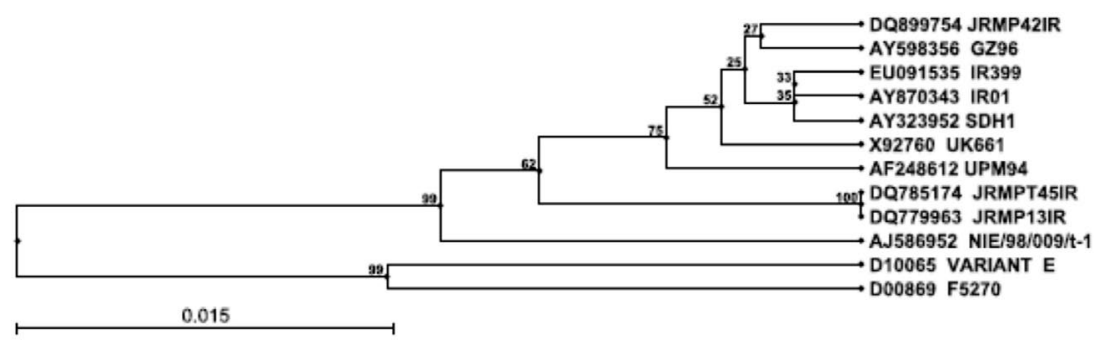

Fig. 2

Phylogenetic tree of selected IBDV strains based on the nucleotide sequence of a part of VP2 gene Branched distances correspond to a sequence divergence. 
Table 1. Nucleotide differences at certain positions in VP2 sequence of selected IBDV strains compared with F52/70 reference strain ${ }^{\mathrm{a}}$

\begin{tabular}{|c|c|c|c|c|c|c|c|c|c|c|c|c|c|c|c|c|c|}
\hline \multirow{2}{*}{$\begin{array}{l}\text { Strain/ } \\
\text { isolate }\end{array}$} & \multicolumn{17}{|c|}{ Nucleotide positions } \\
\hline & 775 & 794 & 802 & 808 & 826 & 829 & 832 & 838 & 847 & 856 & 865 & 868 & 874 & 896 & 904 & 907 & 919 \\
\hline $\mathrm{F} 52 / 70$ & A & $\mathrm{C}$ & G & A & $\mathrm{C}$ & $\mathrm{C}$ & $\mathrm{T}$ & $\mathrm{T}$ & $\mathrm{C}$ & $\mathrm{T}$ & G & $\mathrm{C}$ & $\mathrm{T}$ & G & $\mathrm{C}$ & $\mathrm{C}$ & $\mathrm{T}$ \\
\hline Variant E & . & A & . & & . & . & . & $\mathrm{C}$ & $\mathrm{T}$ & . & & . & $\mathrm{C}$ & . & $\mathrm{T}$ & . & . \\
\hline UK661 & . & G & . & . & $\mathrm{T}$ & $\mathrm{T}$ & $\mathrm{C}$ & $\mathrm{C}$ & . & $\mathrm{C}$ & A & . & . & A & $\mathrm{T}$ & $\mathrm{T}$ & . \\
\hline GZ96 & . & $\mathrm{G}$ & . & . & $\mathrm{T}$ & $\mathrm{T}$ & $\mathrm{C}$ & $\mathrm{C}$ & $\mathrm{T}$ & $\mathrm{C}$ & A & . & . & A & $\mathrm{T}$ & $\mathrm{T}$ & . \\
\hline UPM94 & . & G & . & . & . & $\mathrm{T}$ & $\mathrm{C}$ & $\mathrm{C}$ & . & $\mathrm{C}$ & A & . & . & A & $\mathrm{T}$ & $\mathrm{T}$ & . \\
\hline IR01 & . & G & . & . & $\mathrm{T}$ & $\mathrm{T}$ & . & $\mathrm{C}$ & . & $\mathrm{C}$ & A & . & . & A & $\mathrm{T}$ & $\mathrm{T}$ & . \\
\hline IR399 & . & G & . & & $\mathrm{T}$ & $\mathrm{T}$ & $\mathrm{C}$ & $\mathrm{C}$ & . & $\mathrm{C}$ & A & . & . & A & $\mathrm{T}$ & $\mathrm{T}$ & . \\
\hline SDH1 & . & G & . & . & $\mathrm{T}$ & $\mathrm{T}$ & $\mathrm{C}$ & $\mathrm{C}$ & . & $\mathrm{C}$ & A & . & . & A & $\mathrm{T}$ & $\mathrm{T}$ & . \\
\hline JRMP13IR & & G & A & . & $\mathrm{T}$ & $\mathrm{T}$ & $\mathrm{C}$ & $\mathrm{C}$ & $\mathrm{T}$ & $\mathrm{C}$ & A & . & . & A & $\mathrm{T}$ & . & . \\
\hline JRMP42IR & . & G & . & . & $\mathrm{T}$ & A & $\mathrm{C}$ & $\mathrm{C}$ & . & $\mathrm{C}$ & A & . & . & A & $\mathrm{T}$ & $\mathrm{T}$ & . \\
\hline JRMPT45IR & . & G & A & . & $\mathrm{T}$ & $\mathrm{T}$ & $\mathrm{C}$ & $\mathrm{C}$ & $\mathrm{T}$ & $\mathrm{C}$ & A & . & . & A & $\mathrm{T}$ & . & . \\
\hline \multirow[t]{2}{*}{ NIE009t } & $\mathrm{G}$ & $\mathrm{G}$ & . & $\mathrm{G}$ & $\mathrm{T}$ & . & $\mathrm{C}$ & . &. & $\mathrm{C}$ & $\mathrm{A}$ & $\mathrm{T}$ & $\mathrm{C}$ & A & $\mathrm{T}$ & $\mathrm{T}$ & $\mathrm{C}$ \\
\hline & 934 & 940 & 949 & 967 & 976 & 988 & 994 & 997 & 1010 & 1015 & 1026 & 1027 & 1093 & 1099 & 1114 & 1144 & \\
\hline $\mathrm{F} 52 / 70$ & G & G & $\mathrm{C}$ & $\mathrm{T}$ & G & $\mathrm{C}$ & $\mathrm{T}$ & $\mathrm{T}$ & $\mathrm{C}$ & $\mathrm{C}$ & A & $\mathrm{T}$ & A & $\mathrm{T}$ & G & $\mathrm{T}$ & \\
\hline Variant E & . & . & . & $\mathrm{C}$ & . & . & . & $\mathrm{T}$ & . & G & . & $\mathrm{C}$ & . & A & . & $\mathrm{T}$ & \\
\hline UK661 & . & . & . & $\mathrm{C}$ & . & $\mathrm{T}$ & $\mathrm{C}$ & $\mathrm{T}$ & A & G & G & $\mathrm{C}$ & G & . & A & $\mathrm{C}$ & \\
\hline GZ96 & & . & . & $\mathrm{C}$ & A & $\mathrm{T}$ & $\mathrm{C}$ & $\mathrm{T}$ & A & G & G & $\mathrm{C}$ & G & & A & $\mathrm{C}$ & \\
\hline UPM94 & . & . & . & $\mathrm{C}$ & A & $\mathrm{T}$ & $\mathrm{C}$ & $\mathrm{T}$ & A & G & G & $\mathrm{C}$ & G & . & A & $\mathrm{C}$ & \\
\hline IR01 & . & . & . & $\mathrm{C}$ & A & $\mathrm{T}$ & $\mathrm{C}$ & $\mathrm{T}$ & A & G & G & $\mathrm{C}$ & G & . & A & $\mathrm{C}$ & \\
\hline IR399 & . & . & . & $\mathrm{C}$ & A & $\mathrm{T}$ & $\mathrm{C}$ & $\mathrm{T}$ & A & G & G & $\mathrm{C}$ & G & . & A & $\mathrm{C}$ & \\
\hline SDH1 & . & . & . & $\mathrm{C}$ & A & $\mathrm{T}$ & $\mathrm{C}$ & $\mathrm{T}$ & A & G & G & . & G & . & A & $\mathrm{C}$ & \\
\hline JRMP13IR & A & A & . & $\mathrm{T}$ & . & $\mathrm{T}$ & $\mathrm{C}$ & $\mathrm{C}$ & A & G & G & $\mathrm{C}$ & G & . & A & $\mathrm{C}$ & \\
\hline JRMP42IR & . & . & . & $\mathrm{C}$ & A & $\mathrm{T}$ & $\mathrm{C}$ & $\mathrm{T}$ & A & G & G & $\mathrm{C}$ & G & $\mathrm{C}$ & A & $\mathrm{C}$ & \\
\hline JRMPT45IR & A & A & . & $\mathrm{T}$ & . & $\mathrm{T}$ & $\mathrm{C}$ & $\mathrm{C}$ & A & G & G & $\mathrm{C}$ & G & . & A & $\mathrm{C}$ & \\
\hline NIE009t & . & . & $\mathrm{T}$ & $\mathrm{C}$ & & $\mathrm{T}$ & $\mathrm{C}$ & $\mathrm{T}$ & $\mathrm{A}$ & G & $\mathrm{G}$ & . & $\mathrm{G}$ & . & $\mathrm{A}$ & $\mathrm{C}$ & \\
\hline
\end{tabular}

ats indicate the identical sequences as those of F52/70 reference strain.

Table 2. Amino acid differences at certain positions in VP2 sequence of selected IBDV strains compared with F52/70 reference strain ${ }^{\mathrm{a}}$

\begin{tabular}{|c|c|c|c|c|c|c|c|c|c|c|c|c|c|c|c|c|c|c|}
\hline \multirow{2}{*}{$\begin{array}{l}\text { Strain/ } \\
\text { isolate }\end{array}$} & \multicolumn{18}{|c|}{ Amino acid positions } \\
\hline & 222 & 231 & 233 & 242 & 249 & 253 & 254 & 255 & 256 & 270 & 279 & 284 & 290 & 294 & 297 & 299 & 300 & 330 \\
\hline $\mathrm{F} 52 / 70$ & $\mathrm{P}$ & $\mathrm{S}$ & $\mathrm{N}$ & I & $\mathrm{Q}$ & Q & G & $\mathrm{L}$ & $\mathrm{V}$ & A & D & A & M & $\mathrm{L}$ & $\mathrm{P}$ & $\mathrm{N}$ & E & $\mathrm{S}$ \\
\hline Variant $\mathrm{E}$ & $\mathrm{T}$ & . & . & $\mathrm{V}$ & $\mathrm{K}$ & . & $\mathrm{S}$ & . & . & . & $\mathrm{N}$ & . & . & . & . & . & . & . \\
\hline UK661 & A & . & . & . & . & & . & . & I & . & . & . & . & I & . & $\mathrm{S}$ & . & . \\
\hline GZ96 & A & . & . & . & . & . & . & . & I & . & . & . & . & I & . & $\mathrm{S}$ & . & . \\
\hline UPM94 & A & . & . & . & . & . & $\mathrm{S}$ & . & I & $\mathrm{E}$ & . & . & . & I & . & $\mathrm{S}$ & & . \\
\hline IR01 & A & . & . & . & . & . & . & . & I & . & . & . & . & I & . & S & . & . \\
\hline IR399 & A & . & . & . & . & . & . & . & I & . & . & . & . & I & . & $\mathrm{S}$ & . & . \\
\hline SDH1 & A & . & . & . & . & . & . & . & I & . & . & . & . & I & . & S & . & . \\
\hline JRMP13IR & A & . & . & . & . & . & . & . & I & . & . & . & . & I & . & $\mathrm{S}$ & . & . \\
\hline JRMP42IR & A & . & K & . & . & . & . & & I & . & . & . & . & I & . & S & & . \\
\hline JRMPT45IR & A & . & . & . & . & & . & . & I & & . & . & . & I & & $\mathrm{S}$ & . & . \\
\hline NIE009t & A & & . & . & & & . & . & I & & . & . & . & I & & $\mathrm{S}$ & . & . \\
\hline
\end{tabular}

a Dots indicate the identical sequences as those of the F52/70 reference strain. 
radossi et al., 1999). Amino acid sequences of Iranian and Nigerian turkey IBDV isolates were identical and resembled UK661, GZ96 isolates and previously reported Iranian chicken isolates IR01, IR399, SDH1, and JRMP13IR. The serine-rich heptapeptide sequence SWSASGS adjoining the second hydrophilic region of VP2 protein was also found in Iranian turkey isolate similar to other vvIBDVs. It was reported that conservation of SWSASGS sequence was implicated in the virulence of IBDV, although it was found also in attenuated IBDV s (Heine et al., 1991; Yamaguchi et al., 1996). All of the very virulent, classical virulent and variant strains of IBDV contained 4 serine residues within this region.

Phylogenetic analysis based on the nucleotide sequence placed Iranian turkey isolate on the same branch with Iranian chicken isolate JRMP13IR (Fig. 2). Iranian turkey isolate (JRMPT45IR) was also closer to the Nigerian turkey isolate than to other Iranian chicken, European UK661, and Asian GZ96 isolates.

A preliminary challenge experiment using the Iranian turkey isolate (JRMPT45IR) on turkey poults that were anti-IBDV antibody negative, demonstrated the development of white diarrhea and bursal atrophy (data not shown). To elucidate the impact of vvIBDV infection on turkeys, we are planning more comprehensive and comparative experiments using serologic, histopathologic, and molecular methods.

Acknowledgments. This research was funded by the grant No. 7508007/6/1 from the Research Council of the University of Tehran. Authors thank Dr. A. Barin and Prof. Dr. Y.M. Saif for their helpful comments.

\section{References}

Cao YC, Yeung WS, Law M, Bi YZ, Leung FC, Lim BL (1998): Molecular characterization of seven Chinese isolates of infectious bursal disease virus: classical, very virulent and variant strains. Avian Dis. 42, 340-351. doi:10.2307/ $\underline{1592484}$

Chin RP, Yamamoto R, Lin WQ, Lam KM, Farver TB (1984): Serological survey of infectious bursal disease virus serotypes 1 and 2 in California turkeys. Avian Dis. 28, 1026-1036. doi: $10.2307 / 1590279$

Eterradossi N, Arnauld, C, Tekaia F, Toquin D, Le coq H, Rivallan G, Guittet M, Domenech J, van den Berg TP, Skinner MA (1999): Antigenic and genetic relationships between European very virulent infectious bursal disease viruses and an early West African isolate. Avian Pathol. 28, 36-46. doi:10.1080/03079459995028

Eterradossi NC, Saif YM (2008): Infectious bursal disease. In Saif YM, Barnes HJ, Glisson JR, Fadly AM, McDougald LR, Swayne DE (Eds): Diseases of Poultry. 12th ed. Iowa State Press, Ames, IA, pp. 185-208.

Giambrone JJ, Fletcher OJ, Lukert PD, Page RK, Eidson CE (1978): Experimental infection of turkeys with infec- tious bursal disease virus. Avian Dis. 22, 451-458. doi: $10.2307 / 1589300$

Heine HG, Haritou M, Failla P, Fahey K, Azad A (1991): Sequence analysis and expression of the host-protective immunogen VP2 of a variant strain of infectious bursal disease virus which can circumvent vaccination with standard type I strains. J. Gen. Virol. 72, 1835-1843. doi:10.1099/00221317-72-8-1835

Hosseini SD, Omar AR, Aini I (2004): Molecular characterization of an infectious bursal disease virus isolate from Iran. Acta Virol. 48, 79-83.

Islam MR, Zierenberg K, Eterradossi N, Toquin D, Rivallan G, Müller H (2001): Molecular and antigenic characterization of Bangladeshi isolates of infectious bursal disease virus demonstrate their similarities with recent European, Asian and African very virulent strains. J. Vet. Med. Series B 48, 211 221. doi:10.1046/j.14390450.2001.00449.x

Kataria RS, Tiwari AK, Butchaiah G, Kataria JM (2001): Sequence analysis of the VP2 gene hypervariable region of infectious bursal disease viruses from India. Avian Pathol. 30, 501-507. doi:10.1080/03079450120078699

Kibenge FS, McKenna PK, Dybing JK (1991): Genome cloning and analysis of the large RNA segment (segment A) of a naturally avirulent serotype 2 infectious bursal disease virus. Virology 184, 437-440. doi:10.1016/00426822(91)90865-9

McNulty MS, Allan GM, McFerran JB (1979): Isolation of infectious bursal disease virus from turkeys. Avian Pathol. 8, 205-212. doi:10.1080/03079457908418346

McNulty MS, Saif YM (1988): Antigenic relationship of nonserotype 1 turkey infectious bursal disease viruses from the United States and United Kingdom. Avian Dis. 32, 374-375. doi: $10.2307 / 1590830$

Müller H, Islam MR, Raue R (2003): Research on infectious bursal disease - the past, the present and the future. Vet. Microbiol. 97, 153-165. doi:10.1016/j.vetmic.2003.08.005

Owoade AA, Mulders MN, Kohnen J, Ammerlaan W, Muller CP (2004): High sequence diversity in infectious bursal disease virus serotype 1 in poultry and turkey suggests West-African origin of very virulent strains. Arch. Virol. 149, 653-672. doi:10.1007/s00705-003-0270-y

Razmyar J, Peighambari SM (2008)a: Molecular characterization of Iranian infectious bursal disease viruses. Avian Dis. 52, 665-669. doi:10.1637/8280-031008-Reg.1

Razmyar J, Peighambari SM (2008)b: Rapid differentiation between very virulent and classical infectious bursal disease viruses isolated in Iran by RT-PCR/REA. Int. J. Vet. Res. 2, 111-117.

Rosenberger JK, Saif YM, Jackwood DJ (1998): Infectious bursal disease. In Swayne DE, Glisson JR, Jackwood MW, Pearson JE, Reed WM (Eds): Isolation and Identification of Avian Pathogens. 4th ed. American Association of Avian Pathologist, Pennsylvania, pp. 255-266.

Sapats, SI, Ignjatovic J (2000): Antigenic and sequence heterogeneity of infectious bursal disease virus strains isolated in Australia. Arch. Virol. 145, 773-785. doi:10.1007/ $\underline{\mathrm{s} 007050050670}$ 
Sapats SI, Ignjatovic J (2002): Restriction fragment length polymorphism analysis of the VP2 gene of Australian strains of infectious bursal disease virus. Avian Pathol. 31, 559-566. doi:10.1080/0307945021000024625

Shamsara M, Ghorashi SA, Ahmadian G (2006): Cloning and nucleotide analysis of the VP2 gene of a very virulent infectious bursal disease virus isolate from Iran. Acta Virol. 50, 229-234.

van den Berg TP (2000): Acute infectious bursal disease in poultry: a review. Avian Pathol. 29, 175-194. doi:10.1080/ $\underline{03079450050045431}$

Yamaguchi T, Ogawa M, Inoshima Y, Miyoshi M, Fukushi H, Hirai K (1996): Identification of sequence changes responsible for the attenuation of highly virulent infectious bursal disease virus. Virology 223, 219-223. doi:10.1006/viro.1996.0470 Zierenberg K, Nieper H, van den Berg TP, Ezeokoli CD, Voß M, Müller H (2000): The VP2 variable region of African and German isolates of infectious bursal disease virus: comparison with very virulent, "classical" virulent, and attenuated tissue culture-adapted strains. Arch. Virol. 145, 113-125. doi:10.1007/s007050050009

Zierenberg K, Raue R, Müller H (2001): Rapid identification of very virulent strains of infectious bursal disease virus by reverse transcription-polymerase chain reaction combined with restriction enzyme analysis. Avian Pathol. 30, 55-62. doi:10.1080/03079450020023203 E-mail: snow123@ymail.com; fax: 420545211128 